\title{
Lunar phobia in phyllostomid bats at La Ceiba, Tuxpan, Veracruz
}

\section{Fobia lunar en murciélagos filostómidos en la finca La Ceiba, Tuxpan, Veracruz}

\author{
Juan Manuel Pech-Canché1,2*, Paola Denisse Coria Villegas ${ }^{1}$, Ivette Alicia Chamorro-Florescano ${ }^{2}$, José Luis \\ Alanís Méndez ${ }^{2}$, Miguel Á. Lozano-Rodríguez ${ }^{2}$ \\ ${ }^{1}$ Laboratorio de Vertebrados Terrestres, Facultad de Ciencias Biológicas y Agropecuarias, Universidad Veracruzana, Carretera \\ Tuxpan-Tampico km 7.5. Col. Universitaria, Tuxpan, Veracruz, México, CP. 92860 \\ ${ }^{2}$ Cuerpo Académico Preservación y Conservación de Ecosistemas Tropicales, Facultad de Ciencias Biológicas y Agropecuarias, \\ Universidad Veracruzana \\ * Corresponding author: jmpech@gmail.com
}

Scientific note received: February 26, 2016 accepted: May 22, 2017

\begin{abstract}
The term lunar phobia is used to explain the behavior that some nocturnal animals have to avoid periods with greater moonlight intensity. The aim was to determine the effect of the brightness of the new moon and the full moon on the richness, abundance and diversity of the phyllostomid bat community at the La Ceiba estate, Tuxpan, Veracruz, where the study was conducted from October 2013 to February 2014 using five mist nets for two nights per month. We captured 142 bats belonging to eight species, with Artibeus lituratus being the species with the highest records in both lunar phases (74 individuals). Although no significant differences were found in diversity between the two lunar phases, greater cumulative species richness and abundance were recorded in the new moon (eight species, 118 individuals) than the full moon (five species, 24 individuals). The significant decrease in abundance between the new moon and the full moon, mainly of small frugivorous species, indicates that lunar luminosity affects bat activity. It also has an effect on total species richness as three species were exclusively recorded in the new moon phase.
\end{abstract}

Key words: Abundance, Chiroptera, diversity, moon phases, species richness

RESUMEN. El término fobia lunar se emplea para explicar el comportamiento que algunos animales nocturnos presentan al evadir los periodos con mayor luminosidad de la luna. El objetivo fue conocer el efecto de la luminosidad de luna nueva y la luna llena sobre la riqueza, abundancia y diversidad de murciélagos. El estudio se realizó en la finca La Ceiba de octubre 2013 a febrero 2014 empleando cinco redes de niebla durante dos noches por mes. Se capturaron 142 murciélagos pertenecientes a ocho especies, siendo Artibeus lituratus la especie con mayores registros en ambas fases lunares. Aunque no se encontraron diferencias significativas en la diversidad entre ambas fases lunares, se registró una mayor riqueza y abundancia acumulada en la luna nueva con ocho especies y 118 individuos. Lo que demuestra que la luminosidad lunar afecta la actividad de los murciélagos al presentarse una disminución significativa de la abundancia entre la luna nueva y la luna llena, principalmente de especies frugívoras pequeñas, mientras que en la luna nueva se registraron tres especies exclusivas.

Palabras clave: Abundancia, Chiroptera, diversidad, fases lunares, riqueza

\section{INTRODUCTION}

One of the most important characteristics of our planet is the changes in luminosity produced by the Earth's rotation and the oscillating movement of the Moon around the Earth, which results in the new moon, first quarter, full moon and third quarter lunar phases (Muñoz-Delgado 2008). Phobia is a term linked to fear, but in the case of animal behavior, the term lunar phobia is used to explain the behavioral strategy that some nocturnal animals have to avoid periods with the brightest moonlight; 
this phenomenon has been described in different organisms and is mainly associated with a strategy to reduce predation risks (Mori et al. 2014, PratasSantiago et al. 2017).

It is known that bats can alter their behavior and activity with changes in the lunar cycle (Morrison 1978). It has been suggested that lunar phobia is a complex issue that involves a balance between the probability of getting food and the risk of being predated (Saldaña-Vázquez and MunguíaRosas 2013). For that reason, the position of organisms in the trophic chain and their ability to evade predators are the characteristics that best explain the differences in the response of bats to moonlight conditions (Karlsson et al. 2002). Considering that lunar phobia is a phenomenon with divergent evidence in nocturnal mammals (Prugh and Golden 2014), and that there are species of bats that reduce their activity in periods of lunar luminosity (Börk 2006, Mancina 2008), the aim of this study was to determine the effect of the brightness of the new moon and the full moon on the richness, abundance and diversity of bats.

\section{MATERIALS AND METHODS}

\section{Study area}

This study was conducted at La Ceiba $\left(20^{\circ}\right.$ 58.395' $\mathrm{NL}$ and $97^{\circ} 21.281^{\prime} \mathrm{WL}$ ), located in the municipality of Tuxpan, Veracruz. The property covers 30 ha, with oak forest vegetation with isolated ceiba (Ceiba pentandra) trees, in which the canopy is open because the trees are scattered and the understory is scarce due to the management conditions of the property, which also has a body of water of approximately $10 \mathrm{~m}$ in diameter.

\section{Samplings}

The samplings were conducted from october 2013 to february 2014; to have greater contrast in moonlight conditions, the samplings were carried out for two consecutive nights each month in a new moon (absence of illumination) and in a full moon (full illumination), with a total of 20 sampling nights per moon phase.
For the bat captures, five mist nets of $12 \mathrm{~m}$ long and $2.6 \mathrm{~m}$ high were used, two on the edge, two inside of the vegetation and one around the body of water. Because it has been reported that bats are able to detect the position of the nets if they are kept fixed (Winhold and Kurta 2008), each sampling night the nets were moved a few meters to stay in places with the same characteristics. The nets remained open for five hours after sunset (7:00 pm) and were monitored every half hour. All individuals captured were identified with specialized field guides (Medellín et al. 2008, Ramírez-Pulido et al. 2014), then marked with a permanent marker to identify possible recaptures (Marques et al. 2013) and finally released in the same capture site.

\section{Data Analysis}

To estimate the completeness of the sampling by moon phase, the average value of the ICE, Chao 2 and Jacknife 1 estimators, recommended for abundance data in small samples (Hortal et al. 2006), was used, considering $90 \%$ estimated richness as a satisfactory level of sampling effort effectiveness (Moreno and Halffter 2000); those with one or two individuals were considered as rare species (Moreno 2001). To evaluate the cumulative species richness, rarefaction curves were made; the order of the capture nights was randomized 1000 times to smooth the curve and eliminate the bias of the order in which the species were captured, considering the lunar phases as different if their $95 \%$ confidence intervals are not overlaid. The estimators and the rarefaction curve were calculated with EstimateS software version 9.1 (Colwell 2013).

To measure the diversity of bats in the lunar phases, the Shannon-Weaver index (Shannon and Weaver 1949) was used, testing differences between lunar phases using Hutchinson's t-test. To test differences in the average richness and abundance between the lunar phases, a non-parametric Wilcoxon test (W) was performed, because it is a comparison of means with the same sample size, but it does not have a normal distribution. To test differences in abundance by trophic guilds, an $\mathrm{X}^{2}$ test was performed, while to test differences 
Table 1. List of species and diversity parameters of bats at La Ceiba, Tuxpan, Veracruz, Mexico.

\begin{tabular}{cccccc}
\hline Family & Species & Guild & Full moon & New moon & Total \\
\hline Phyllostomidae & Artibeus lituratus & Large frugivore & 13 & 61 & 74 \\
Phyllostomidae & Artibeus jamaicensis & Large frugivore & 3 & 19 & 22 \\
Phyllostomidae & Glossophaga soricina & Nectarivore & 5 & 18 & 23 \\
Phyllostomidae & Dermanura phaeotis & Small frugivore & & 3 & 3 \\
Phyllostomidae & Sturnira parvidens & Small frugivore & 1 & 4 & 5 \\
Phyllostomidae & Sturnira hondurensis & Small frugivore & 2 & 7 & 9 \\
Phyllostomidae & Chiroderma salvini & Small frugivore & & 4 & 4 \\
Phyllostomidae & Chiroderma villosum & Small frugivore & 5 & 2 & 2 \\
& & Richness & 5 & 8 & \\
& & Abundance & 24 & 118 & \\
& & ICE & 5.75 & 8.56 & \\
& & Chao 2 & 5 & 8 & \\
& & Jacknife 1 & 5.88 & 8.88 & \\
& & Percentage of completeness & 90 & 94 & \\
\hline
\end{tabular}
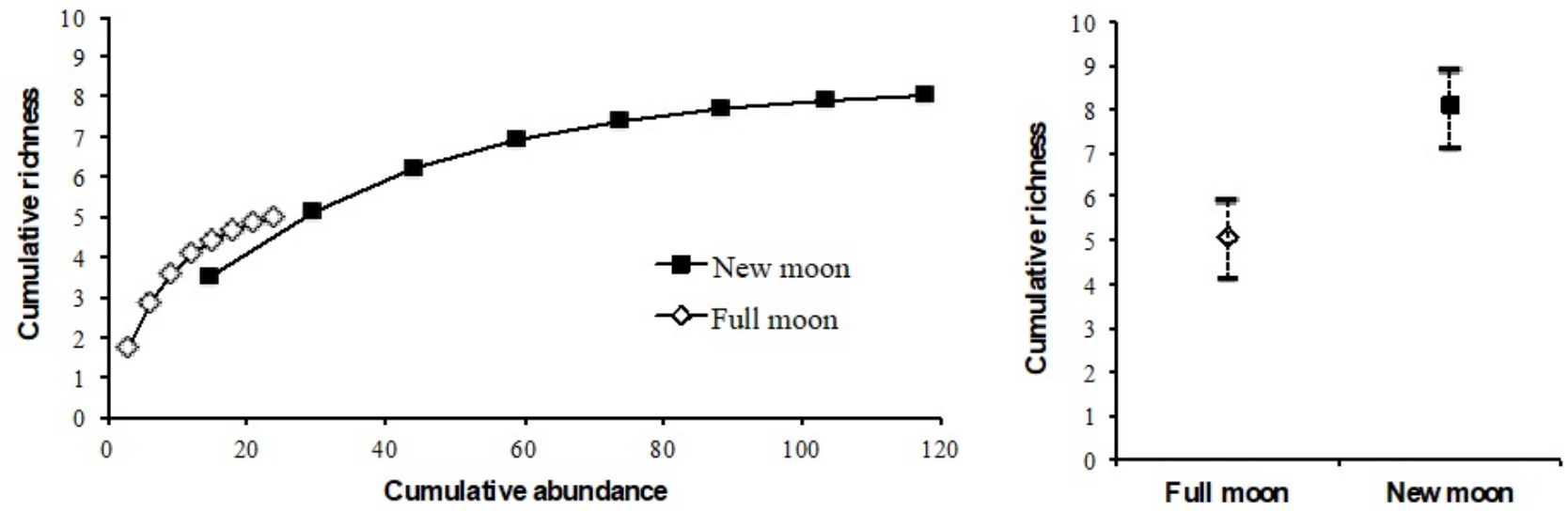

Figure 1. Rarefaction curve (a) and species richness ( $\pm 95 \%$ confidence intervals) (b) of bats in the full and new moon phases at La Ceiba, Tuxpan, Veracruz.

in proportions by guilds, a $G$ test was performed for contingency tables (Zar 2010). The analyses were based on the Simmons and Voss (1998) classification system, which includes the subfamilies Carollinae and Sternodermatinae as frugivorous and the subfamily Glossophaginae as nectarivorous; for the frugivorous species, a separation of large and small species was carried out (Pinto and Keitt 2008).

\section{RESULTS AND DISCUSSION}

In total, 142 bats belonging to eight species were captured (Table 1). The greatest richness and abundance were recorded in the new moon with eight species and 118 individuals, while in the full moon there were five species and 24 individuals. The sampling efficiency can be considered satisfactory, since in both lunar phases at least $90 \%$ completeness was reached. The rarefaction curve shows that the new moon had the highest cumulative richness and abundance, while in the full moon the richness and abundance were lower (Figure 1). There were only significant statistical differences in the average abundance in the lunar phases ( $W=24$, $p=0.048)$, but no differences were detected when comparing average richness $(W=9, p=0.52)$. The Shannon-Weaver diversity index was 1.48 for the new moon and 1.26 for the full moon, with no statistical differences between the lunar phases. 

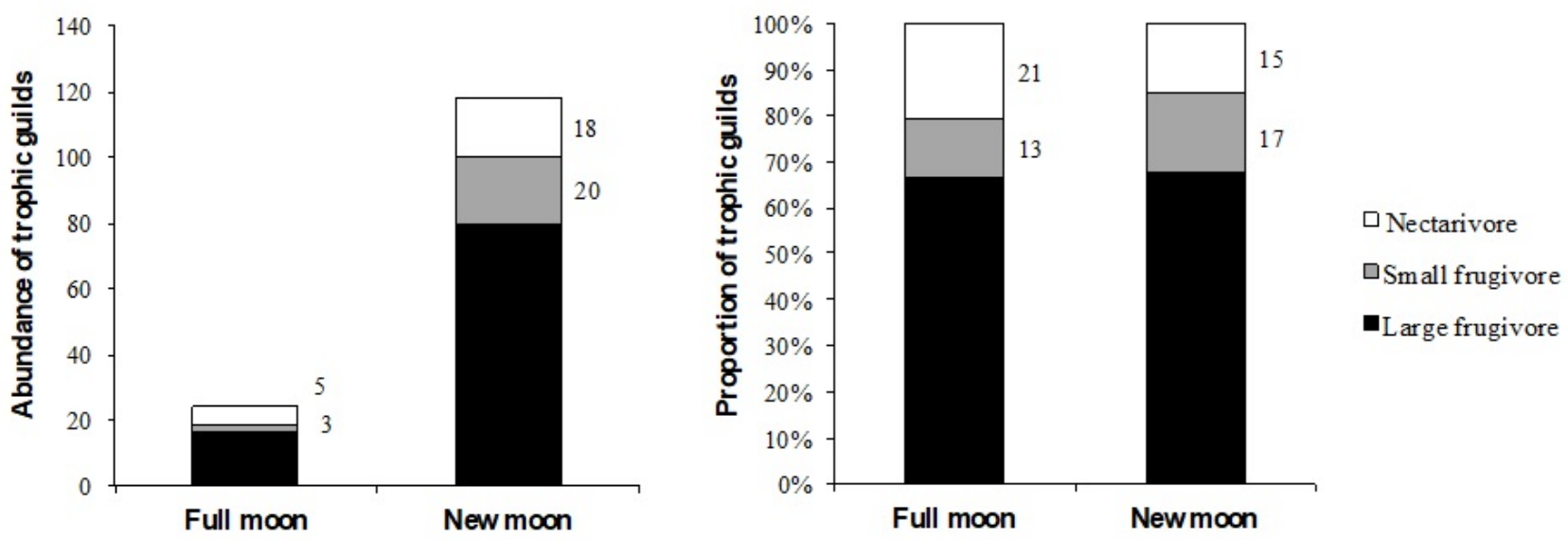

Figure 2. Abundance (a) and proportion (b) of trophic guilds in both lunar phases analyzed.

Species belonging to the trophic guilds were recorded: large frugivores, small frugivores and nectarivores, with significant differences in the abundance of the guilds by moon phase $\left(X^{2}=3.5, p=\right.$ $0.01)$, but not between the proportions of the guilds (Figure 2). Most of the species captured belong to the small frugivore guild (five species), which were detected in the new moon, but the large frugivore guild had the greatest abundance (96 individuals), while the least represented guild was that of the nectarivores, with one species. Therefore, the results show that phyllostomid bat species modify their activity level depending on the lunar phase, exhibiting a lunar phobia effect that is reflected in the reduced abundance of frugivorous species in the full moon. This pattern coincides with that reported for frugivorous bats by Santos-Moreno et al. (2010), Mello et al. (2013), and Saldaña-Vázquez and Munguía-Rosas (2013), nectarivorous (Mancina 2008) and piscivorous bats (Börk 2006), and even as reported by Lewanzik and Voigt (2014), who show that lighting can affect the feeding behavior of frugivorous species.

The failure to detect significant differences between the diversity, average species richness and proportion of trophic guilds in the lunar phases may indicate that there is no spatial displacement of the species to another site, but that they only restrict their activity in the hours of less luminosity, possibly as a strategy to reduce the risk of predation, since it has been reported that in the absence of predators, bats do not alter their activity during the different lunar phases (Gannon and Willig 1997).

The results may also be due to the low species richness recorded in the study area, since in other sites an inverse and significant relationship of species richness and lunar luminosity has been reported (Esbérard 2007). In the present study, this could be supported by the recording of three exclusive species in the new moon phase, which suggests that during this period there may be a greater probability of recording more species; in addition, sampling in bright conditions (full moon) could cause a sub-representation of the total species richness of a site in relation to samplings in lower luminosity conditions (new moon), by recording a smaller number of species than those actually found in a certain area, especially small-sized species that have a smaller displacement capacity than large ones (Pinto and Keitt 2008).

The analysis of trophic guilds shows that lunar phobia mainly affects abundance, since the proportions of the trophic guilds remain similar in both lunar phases, but there is an $80 \%$ reduction in abundance in the full moon phase. However, this would only be applicable to the phytophagous species (fru- 
givorous and nectarivorous), which are the ones that have greater detectability with the capture methods used (Meyer et al. 2011), since it has been reported that insectivorous species can be less affected by lunar phobia due to their faster flight (Karlsson et al. 2002, Appel et al. 2017). In order to have a more robust conclusion, it is necessary to implement indirect recording techniques, such as ultrasonic detectors, that allow an adequate characterization of the diversity of insectivorous bats (Pech-Canché et al. 2010).

\section{ACKNOWLEDGEMENTS}

We wish to thank Dulce Deménegui for the ability to work on the estate, to all the people who accompanied us during the field work, and to the editor and the three anonymous reviewers who helped improve the quality of the manuscript.

\section{LITERATURE CITED}

Appel G, López-Baucells A, Magnusson WE, Bobrowiecd PED (2017) Aerial insectivorous bat activity in relation to moonlight intensity. Mammalian Biology 85: 37 - 46

Börk KS (2006) Lunar phobia in the greater fishing bat (Noctilio leporinus) (Chiroptera: Noctilionidae). Revista de Biología Tropical 54: 1117 - 1123.

Colwell RK (2013) EstimateS: Statistical estimation of species richness and shared species from samples. Version 9. http://viceroy.colorado.edu/estimates/. Data consulted: February 20, 2016.

Esbérard CEL (2007) Influência do ciclo lunar na captura de morcegos Phyllostomidae. Iheringia, Sér. Zool., Porto Alegre 97: 81 - 85.

Gannon M, Willig M (1997) The effect of lunar illumination on movement and activity of the red fig-eating bat (Stenoderma rufum). Biotropica 29: 525 - 529

Hortal J, Borges PAV, Gaspar C (2006) Evaluating the performance of species richness estimators: sensitivity to sample grain size. Journal of Animal Ecology 75: 274 - 287.

Karlsson B, Eklóf J, Rydell J (2002) No lunar phobia in swarming insectivorous bats (Family Vespertilionidae). Journal of Zoology 256: 473 - 477.

Lewanzik D, Voigt CC (2014) Artificial light puts ecosystem services of frugivorous bats at risk. Journal of Applied Ecology. 51: 388 - 394.

Mancina C (2008) Effect of moonlight on nocturnal activity of two Cuban nectarivores: the Greater Antillean long-tongued bat (Monophyllus redmani) and Poey's flower bat (Phyllonycteris poeyi). Bat Research News 49: $71-74$.

Marques TJ, Pereira-Ramos MJ, Marques TA, Santos CA, Santana J, Beja P, et al. (2013) Optimizing sampling design to deal with mist-net avoidance in Amazonian birds and bats. Plos One 8: e74505.

Medellín R, Arita HT, Sánchez O (2008) Identificación de los murciélagos de México, guía de campo. 2da ed. Instituto de Ecología, UNAM. México. 80p.

Mello MAR, Kalko EKV, Silva WR (2013) Effects of moonlight on the capturability of frugivorous phyllostomid bats (Chiroptera: Phyllostomidae) at different time scales. Zoología 30: 397 - 402.

Meyer CFG, Aguiar LMS, Aguirre LF, Baumgarten J, Clarke FM, Cosson JF, et al. (2011) Accounting for detectability improves estimates of species richness in tropical bat surveys. Journal of Applied Ecology 48: 777 - 787. 
Moreno CE (2001) Métodos para medir la biodiversidad. M\&T-Manuales y Tesis SEA, CYTED, ORCYT/UNESCO Y SEA. Zaragoza, España. 84p.

Moreno CE, Halffter G (2000) Assessing the completeness of bat biodiversity inventories using species accumulation curves. Journal of Applied Ecology 37: 149 - 158.

Mori E, Nourisson DH, Lovari S, Romeo G, Sforzi A (2014) Self-defence may not be enough: moonlight avoidance in a large, spiny rodent. Journal of Zoology. 294: $31-40$.

Morrison DW (1978) Lunar phobia in a Neotropical fruit bat, Artibeus jamaicensis (Chiroptera: Phyllostomidae). Animal Behaviour 26: 852 - 855.

Muñoz-Delgado J (2008) A propósito de los ritmos de la luna. Ciencias 59: 48 - 56.

Pech-Canché JM, MacSwiney MCG, Estrella E (2010) Importancia de los detectores ultrasónicos para mejorar los inventarios de murciélagos Neotropicales. Therya 1: 221 - 228.

Pinto N, Keitt TH (2008) Scale-dependent responses to forest cover displayed by frugivore bats. Oikos 117 : $1725-1731$.

Pratas-Santiago LP, Gonçalves ALS, Nogueira AJA, Spironello WR (2017) Dodging the moon: The moon effect on activity allocation of prey in the presence of predators. Ethology. 123: $467-474$.

Prugh LR, Golden CD (2014) Does moonlight increase predation risk? Meta-analysis reveals divergent responses of nocturnal mammals to lunar cycles. Journal of Animal Ecology 83: 504 - 514

Ramírez-Pulido J, González-Ruiz N, Gardner A, Arroyo-Cabrales J (2014) List of Recent Land Mammals of Mexico, 2014. Special Publications Museum of Texas. Tech University 63: 1 - 69.

Saldaña-Vázquez R, Munguía-Rosas MA (2013) Lunar phobia in bats and its ecological correlates: A metaanalysis. Mammalian Biology 78: 216 - 219.

Santos-Moreno A, Ruiz E, Sánchez Martínez A (2010) Efecto de la intensidad de la luz lunar y de la velocidad del viento en la actividad de murciélagos filostómidos de Mena Nizanda, Oaxaca, México. Revista Mexicana de Biodiversidad 81: 839 - 845

Shannon CE, Weaver W (1949). The mathematical theory of communication. Illinois: University of Illinois Press. USA. 117p.

Simmons NB, Voss RS (1998) The mammals of Paracou, French Guiana: A Neotropical lowland rainforest fauna. Part 1. Bats. Bulletin of the American Museum of Natural History 237: 1 - 219.

Winhold L, Kurta A (2008) Netting surveys for bats in the Northeast: differences associated with habitat, duration of netting, and use of consecutive nights. Northeastern Naturalist 15: $263-274$.

Zar J (2010) Biostatistical analysis. 5th. Edition. Prentice Hall. USA. 663p. 